This is an author produced version of a paper published in Environmental Pollution.

This paper has been peer-reviewed and is proof-corrected, but does not include the journal pagination.

Citation for the published paper:

Bengtsson, Stefan B; Eriksson, Jan; Gärdenäs, Annemieke I; Vinichuk, Mykhalio; Rosén, Klas. (2013) Accumulation of wet-deposited radiocaesium and radiostrontium by spring oilseed rape (Brássica napus L.) and spring wheat (Tríticum aestívum L.). Environmental Pollution. Volume: 182, pp 335-342. http://dx.doi.org/10.1016/j.envpol.2013.07.035.

Access to the published version may require journal subscription. Published with permission from: Elsevier.

Epsilon Open Archive http://epsilon.slu.se 


\title{
Accumulation of wet-deposited radiocaesium and radiostrontium by spring oilseed rape (Brássica napus L.) and spring wheat (Tríticum aestívum L.)
}

\author{
Stefan B. Bengtsson ${ }^{\mathrm{a}}$, Jan Eriksson ${ }^{\mathrm{a}}$, Annemieke I. Gärdenäs ${ }^{\mathrm{a}}$, Mykhalio Vinichuk $^{\mathrm{b}}$, Klas Rosén ${ }^{\mathrm{a}}$ \\ ${ }^{\mathrm{a}}$ Swedish University of Agricultural Sciences, Department of Soil and Environment, P.O. Box 7014, SE-75007 \\ Uppsala, Sweden

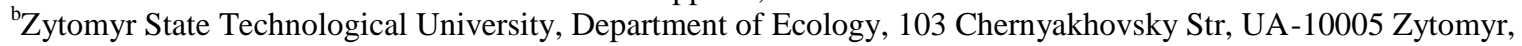 \\ Ukraine
}

Published 2013 in Environmental Pollution 182(2013), 335-342

\begin{abstract}
The accumulation of ${ }^{134} \mathrm{Cs}$ and ${ }^{85} \mathrm{Sr}$ within different parts of spring oilseed rape and spring wheat plants was investigated, with a particular focus on transfer to seeds after artificial wet deposition at different growth stages during a two-year field trial. In general, the accumulation of radionuclides in plant parts increased when deposition was closer to harvest. The seed of spring oilseed rape had lower concentrations of ${ }^{85} \mathrm{Sr}$ than spring wheat grain. The plants accumulated more ${ }^{134} \mathrm{Cs}$ than ${ }^{85} \mathrm{Sr}$. We conclude that radionuclides can be transferred into human food chain at all growing stages, especially at the later stages. The variation in transfer factors during the investigation, and in comparison to previous results, implies the estimation of the risks for possible transfer of radionuclides to seeds in the events of future fallout during a growing season is still subjected to considerable uncertainty.
\end{abstract}

Keywords: Concentration, Radionuclide, Transfer factor, Translocation factor

\section{Introduction}

Radionuclides intercepted in plants can be taken up and redistributed to edible plant parts, for examples seeds. The rate of uptake and redistribution of radionuclides depends on growth stage of the crop, weather conditions and the type of radionuclide (IAEA, 2010; Kinnersley et al., 1997; Pröhl, 2009), and radionuclide uptake is through either foliage (foliar uptake) or roots (root uptake). Foliar uptake is assumed the dominant pathway when deposition occurs during the growing season (Pröhl, 2009); as a well-developed crop with its large leaf area intercepts a majority of the deposited radionuclides (Bengtsson et al., 2012; Vandecasteele et al., 2001). The cuticle layer of the leaf epidermis is assumed to be impermeable; however, it contains cracks and defects where radionuclides can enter (Handley and Babcock, 1972; Hossain and Ryu, 2009; Tukey et al., 1961). The rate of radionuclide entrance through the cuticle layer depends on different physical and chemical factors, such as temperature, light, $\mathrm{pH}$, the carrier of the radionuclide in the solution, the valence of the radionuclides, and the type of crop (Tukey et al., 1961). Radionuclides can also enter the plant system through the stomata, but this pathway is assumed to contribute a small fraction of the total amount of radionuclides entering the leaf (Eichert and Burkhardt, 2001; Eichert et al., 2002; Tukey et al., 1961). Similarly, the time of the crops harvest affected the redistributionof the radionuclides within the crop (Coughtrey and Thorne, 1983; Kirchmann et al., 1967; Tukey et al., 1961). When radionuclides enter through the cuticle layer, they are actively transported inside the plant cells through both the symplastic pathway and an exchange mechanism between the phloem and xylem i.e. vascular bundle system (Thiessen et al., 1999). The redistribution of radionuclides is regulated mainly by their physiological behavior within the crop and the time during the growing season when the deposition occurred (Thiessen et al., 1999).

The monovalent radiocaesium ion is redistributed within crops to a higher degree than the divalent radiostrontium ion (Aarkrog, 1969, 1975, 1983; Eriksson et al., 1998; Müller and Pröhl, 1993). The redistribution of radiocaesium through the vascular bundle system takes place at different rates depending on the plant part targeted: $5-30 \%$ of the intercepted radiocaesium is taken up through the epidermis, and of this, about one-third is redistributed to the seeds (Coughtrey and Thorne, 1983). However, of the entrance of radiocaesium into crops occurs at an early growth stage or just before harvest, the degree of redistribution to the seeds is lower than if entrance of 
radiocaesium occurs at the time of seed development (Coughtrey and Thorne, 1983).

Radiostrontium is retained by the cuticle layer of the epidermis to a higher degree than radiocaesium (Vadecasteele et al., 2001), therefore, there is less redistribution to other plant parts in the vascular bundle system (Aarkrog, 1969, 1975, 1983; Bréchignac et al., 2000; Müller and Pröhl, 1993). A maximum of $25 \%$ of the total radiostrontium taken up by cereals is redistributed to other plant parts within the vascular bundle system of which $5-10 \%$ of the radiostrontium being redistributed to the grain, and up to $50 \%$ to the roots (Coughtrey and Thorne, 1983).

The transfer of radionuclides from the environment to edible plant parts in a given situation can be described by a transfer factor (TF, $\left.\mathrm{m}^{2} \mathrm{~kg}^{-1}\right)$. This is defined as a ratio between the activity concentration of radionuclides in plant parts $\left(\mathrm{Bq} \mathrm{kg}^{-1}\right)$, for example seeds, and the amount of radionuclides deposited per unit area $\left(\mathrm{Bq} \mathrm{m}^{-2}\right)$ (Ehlken and Kirchner, 2002; Howard et al., 1996; Rosén et al., 1996). Transfer factors have only been determined for a limited number of possible scenarios and have strong seasonal variation (IAEA, 2010). If a TF value relevant for a specific situation, i.e. determined under similar circumstances, is unavailable, the assessment of the situation after deposition of radioactivity can be challenging and wrong decisions, either too cautious or too careless, about suitable measures for preventing the transfer of radionuclides to foodstuffs may be made (Salbu, 2000). The transfer of the intercepted radionuclides to edible plant parts can be described by a translocation factor (TLF, $\mathrm{m}^{2} \mathrm{~kg}^{-1}$ ). This is defined as the ratio between the activity concentration of radionuclides in plant parts $\left(\mathrm{Bq} \mathrm{kg}^{-1}\right)$, for example seeds, and the amount of intercepted radionuclides by the plant canopy per unit area $\left(\mathrm{Bq} \mathrm{m}^{-2}\right)$ (Thiessen et al., 1999; Vadecasteele et al., 2001).

The aims of this study were to investigate ${ }^{134} \mathrm{Cs}$ and ${ }^{85} \mathrm{Sr}$ accumulation in spring oilseed rape (Brássica napus L.) and spring wheat (Tríticum aestívum L.) after wet deposition at different growth stages; to calculate the distribution of ${ }^{134} \mathrm{Cs}$ and ${ }^{85} \mathrm{Sr}$ between plant parts; and, to describe transfer of ${ }^{134} \mathrm{Cs}$ and ${ }^{85} \mathrm{Sr}$ to seeds through TF and TLF values. The hypothesis was ${ }^{134} \mathrm{Cs}$ and ${ }^{85} \mathrm{Sr}$ accumulation in seeds depends on the growth stage of the plant, the type of radionuclide, and the plant type.

\section{Materials and methods}

\subsection{Study area}

The study was conducted at the Ultuna meteorological and agricultural field station, Uppsala, Sweden $\left(59^{\circ} 48^{\prime} 45^{\prime \prime} \mathrm{N}\right.$ and $\left.17^{\circ} 38^{\prime} 45^{\prime \prime} \mathrm{E}\right)$. The texture of the soil at the site was clay (60\% clay, $20 \%$ silt and $20 \%$ sand). Soil texture, $\mathrm{pH}$ (6.5), plant available phosphorous (57 mg kg ${ }^{-1}$ ), potassium (202 mg kg-1) and calcium (3692 $\mathrm{mg} \mathrm{kg}^{-1}$ ) were determined in 2010 and described by Bengtsson et al. (2012).

The meteorological station, described by Karlsson and Fagerberg (1995), monitors daily air temperature, precipitation, and wind speed. The long-term (30 years, 1961-1990) annual mean air temperature was $5.6{ }^{\circ} \mathrm{C}$ and the annual mean precipitation sum was $588 \mathrm{~mm}$ (SMHI, 2012). The growing season from $1^{\text {st }}$ May to $30^{\text {th }}$ of September 2010 had a mean air temperature of $15{ }^{\circ} \mathrm{C}$ and precipitation sum of $293 \mathrm{~mm}$ (Department of Crop Production Ecology, 2013). During the second growing season in 2011, mean air temperature was 15 ${ }^{\circ} \mathrm{C}$ and precipitation sum $287 \mathrm{~mm}$ (Department of Croop Production Ecology, 2013). The temperature at the deposition and sampling occasions varied between 10 and $21{ }^{\circ} \mathrm{C}$ and there was no precipitation in connection with deposition and sampling on any occasion during the years of study (2010 and 2011), except for the last deposition and sampling occasion for spring wheat in $2011(0.1 \mathrm{~mm})$ (Department of Crop Production Ecology, 2013). Wind speed at deposition and sampling occasions was low; it varied between 1.3 and $3.6 \mathrm{~m} \mathrm{~s}^{-1}$ in 2010, and, 1.3 and $2.7 \mathrm{~m}$ $\mathrm{s}^{-1}$ in 2011 (Department of Crop Production Ecology, 2013).

\subsection{Design of the trial}

A trial with a randomized block design, with $1 \times 1 \mathrm{~m}^{2}$ parcels in three replicates (in total 60 parcels), was laid out in 2010. In order to cover seasonal variations, a new trial with the same design was laid on a nearby site in 2011. The experimental crops, spring oilseed rape (Brássica napus L.) variety 'Larissa' and spring wheat (Tríticum aestívum L.) variety 'Triso', were sown 12 May 2010 and 27 April 2011 as described in Bengtsson et al. (2012) and managed according to common agricultural practices for the region. The radionuclides selected for the field experiment were ${ }^{134} \mathrm{Cs}$ (half-life of 2.07 years) and ${ }^{85} \mathrm{Sr}$ (half-life of 64.9 days): it was assumed these radionuclides behaved in the same manner as ${ }^{137} \mathrm{Cs}$ and ${ }^{90} \mathrm{Sr}$. The selected radionuclides were applied through artificial rain.

The radionuclides were deposited on plants on spring oilseed rape at five different growth stages, which were according to the Biologische Bundesanstalt, Bundessortenamt und Chemische Industrie (BBCH)scale, (Hack et al., 1992). In 2010 these stages were leaf development, code 13 (three leafs unfold); stem elongation, code 32 (two visible extended internodes); $10 \%$ of flowers on main raceme open, code 61; full flowering, code 65 ; and, beginning of ripening, code 80. In 2011, the growth stages were leaf development, codes 15-19 (five to nine leafs unfold); full flowering, 
code 65 ; end of flowering, code 69 ; development of fruit, code 76 (60\% of pods have reached final size); and, ripening, code 82 (20\% of pods ripe, seeds dark and hard) (Fig. 1a).

For the spring wheat in 2010, the growth stages, according to the $\mathrm{BBCH}$-scale were tillering, code 21 (headshot and one side shot); stem extension, code 37 (flag leaf visible); flowering, code 65 (on-going flowering); development of fruit, code 70 (medium milk); and, ripening, fully ripe, code 89 . In 2011, the growth stages were stem extension, code 37 (flag leaf visible); flowering, code 65 (on-going flowering); ripening, code 85 (dough ripeness); ripening, fully ripe, code 89; and, senescence, over-ripe, code 92 (Fig. 1b).

\subsection{Preparation and deposition of artificial radioactive rain}

The artificial rainwater solution was prepared from stock solutions as described by Bengtsson et al. (2012). In 2010 the stock solutions contained $5 \mathrm{MBq} \mathrm{L}^{-1134} \mathrm{Cs}$ and $15 \mathrm{MBq} \mathrm{L}{ }^{-1}{ }^{85} \mathrm{Sr}$ and in 2011 , they contained 40 $\mathrm{MBq} \mathrm{L}{ }^{-1}{ }^{134} \mathrm{Cs}$ and $37 \mathrm{MBq} \mathrm{L}^{-1}{ }^{85} \mathrm{Sr}$. ${ }^{134} \mathrm{Cs}$ was in the form of caesium chloride $(\mathrm{CsCl})$ in $0.1 \mathrm{M} \mathrm{HCl}$ solution (Expanded uncertainty of $\pm 10 \%$ ) (Institute of Atomic Energy POLATOM, Otwock-Swierk, Poland). ${ }^{85} \mathrm{Sr}$ was in the form of strontium chloride $\left(\mathrm{Sr} \mathrm{Cl}^{2}\right)$ in $0.1 \mathrm{M}$ $\mathrm{HCl}$ solution (expanded uncertainty of $\pm 2.5 \%$ ) (Areva Cerca Lea, Pierrelatte Cedex, France). In 2010 the amount of ${ }^{134} \mathrm{Cs}$ applied at the different growth stages ranged from 24.5 to $30.9 \mathrm{kBq} \mathrm{m}^{-2}$ and ${ }^{85} \mathrm{Sr}$ ranged from 28.5 to $49.8 \mathrm{kBq} \mathrm{m}^{-2}$. In 2011, the amount of ${ }^{134} \mathrm{Cs}$ ranged from 40.2 to $41.0 \mathrm{kBq} \mathrm{m}^{-2}$ and ${ }^{85} \mathrm{Sr}$ ranged from 39.4 to $41.0 \mathrm{kBq} \mathrm{m}^{-2}$.

The radionuclides were applied with a rainfall simulator, as described in Bengtsson et al. (2012). The simulator was a modified version of the drip infiltrometer developed by Joel and Messing (2001). The amount of precipitation applied at each treatment

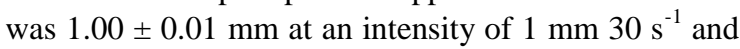
the equipment used was a 520 series process pump manufactured by Watson-Marlow. A windshield was used to prevent wind disturbance during deposition in the early growth stages.

\subsection{Sampling and analyses}

In both years plants were cut $5 \mathrm{~cm}$ above ground within a frame $(25 \times 25 \mathrm{~cm} 2$ square $)$ placed in the middle of each parcel two-three hours after deposition in three replicates, and in another three at harvest time (when plants were fully ripe): the whole plants were sampled. Spring oilseed rape was separated into four plant compartments; stem (stem and attached dead leaves), siliques (except seeds), and remaining seed materials. Likewise spring wheat was separated into four plant compartments; stem (stem and attached dead leaves), ears (husks) except seeds, and the seeds.
The plant materials were weighed fresh, and then airdried (at a maximum of $40{ }^{\circ} \mathrm{C}$ for a minimum of 14 days) before being re-weighed for dry weight (d.w.). Thereafter, the plant material was milled and placed in $35 \mathrm{~mL}$ or $60 \mathrm{~mL}$ plastic jars with a suitable geometry for measuring activity concentration. The activity concentration of the radionuclides were expressed as $\mathrm{Bq} \mathrm{kg}{ }^{-1}$ d.w. and corrected for the decay between sampling and analysis. The results obtained for sampling from early growth stages measured in $35 \mathrm{~mL}$ jars were corrected for the degree of filling due to small amount of plant material; the correction factor for each detector was determined according to Bengtsson et al. (2012).

The actual concentration of radionuclides in the artificial rainwater and in the plant materials were measured by High Purity Germanium (HPGe)detectors (GMX-13200, GMX-33210, GMX-20200), and the measured activity concentrations were analysed and presented with the computer software Genie $^{\text {TM }} 2000$ (C) Canberra, Meriden, Connecticut, USA, 2009). The activity concentrations measured included uncertainties of the efficiency calibration of the HPGe-detector, which was assumed to be one of the main sources of the total uncertainty that was measured (Bronson et al., 2008); the details are presented in Bengtsson et al. (2012). Uncertainty of the total amount of radionuclides deposited was estimated according to the method described in the Guide to the Expression of Uncertainty in Measurement (GUM) (Ellison et al., 2000; ISO, 1993), and was reported as the combined standard uncertainty $u_{c}(y)$.

To determine whether different deposition occasions affected the total concentration in above ground plant at harvest similarly in both crops, each radionuclide was linearly regressed and the concentration ins spring wheat was plotted against the concentration in spring oilseed rape (test 1 in Table 2), with one plot for each year. In the second test to determine whether different deposition occasions affected the total concentration of the two radionuclides in seeds at harvest similarly in both crops, the ${ }^{85} \mathrm{Sr}$ concentration from the linear regression for each crop was plotted against ${ }^{134} \mathrm{Cs}$ concentration in seeds (test 2 in Table 2), with one plot for each year. Whether the radionuclides were transferred to the seeds similarly for each crop during the two years of the experiment was also tested (Test 3 in Table 2). Balanced analyses of variance (ANOVA) were applied for TF and TLF values. All statistical analyses were with the computer program $\mathrm{R}$ version 2.15.2 (@) The R Foundation for Statistical Computing, Vienna, Austria, 2012).

\subsection{Calculations of TF and TLF}

The transfer factors for ${ }^{134} \mathrm{Cs}$ and ${ }^{85} \mathrm{Sr}\left(\mathrm{TF}, \mathrm{m}^{2} \mathrm{~kg}^{-1}\right)$ were calculated as the activity concentration of a 
specific radionuclide in edible plant parts, in this instance seeds, at harvest $\left(A_{c}, \mathrm{~Bq} \mathrm{~kg}^{-1}\right)$ divided by the amount of deposited activity $\left(A_{t}, \mathrm{~Bq} \mathrm{~m}^{-2}\right)$ (Equation (1): Howard et al., 1996; Rosén e al., 1996, 2011).

$\mathrm{TF}=A_{c} / A_{t} \quad\left[\mathrm{~m}^{2} \mathrm{~kg}^{-1}\right]$

The translocation factor for ${ }^{134} \mathrm{Cs}$ and ${ }^{85} \mathrm{Sr}$ (TLF, $\mathrm{m}^{2}$ $\mathrm{kg}^{-1}$ ) were calculated as activity concentration of a specific radionuclide in edible plant parts, in this instance seeds, at harvest $\left(A_{c}, \mathrm{~Bq} \mathrm{~kg}^{-1}\right)$ divided by the amount of intercepted activity at deposition by the plant $\left(A_{i}, \mathrm{~Bq} \mathrm{~m}^{-2}\right)$ (Equation (2): Thiessen et al., 1999; Vadecasteele et al., 2001).

$\mathrm{TLF}=A_{c} / A_{i} \quad\left[\mathrm{~m}^{2} \mathrm{~kg}^{-1}\right]$

\section{Results and discussions}

\section{1 ${ }^{134} \mathrm{Cs}$ and ${ }^{85} \mathrm{Sr}$ activity concentration in plants}

Generally, if deposition took place later in the growing season, the activity concentrations of ${ }^{134} \mathrm{Cs}$ and ${ }^{85} \mathrm{Sr}$ became higher in different plant parts of both crops (Table 1), with the siliques (except seeds) and husk having the highest activity concentration and amounts of both radionuclides. The exception was spring oilseed rape, where straw in 2010 had the highest activity concentration of ${ }^{134} \mathrm{Cs}$. In whole above-ground plant of spring wheat the activity concentration of radiostrontium was higher than the activity concentration of radiocaesium. The total concentrations in the above ground plant parts of both crops were correlated (test 1 in Table 2, spring wheat all plant parts vs. spring oilseed rape all plant parts, by radionuclide and by year, see Supplementary data 4 for the plots), indicating that growth stage affects both radionuclides in a similar way.

The average activity concentrations in seeds at harvest varied with the time of deposition for both crops. Activity concentrations were lowest when deposition was during the early growth stages, slightly higher at deposition during the growth of the crops and flowering and highest at late deposition in the ripening phase (Table 1). Lower transfer during early growth stages can be a result of lower interception and retention of radionuclides due to fall-off and wash-off in early growth sages (Colle et al., 2009). At growth stage 65 in 2010 the values for ${ }^{134} \mathrm{Cs}$ in spring oilseed rape were lower that at previous growth stages probably due to experimental error (Table 1). Even so, the increase in radionuclide concentration in seeds with development stage was less than for other plant parts (straw and siliques), which might be due to dilution as seed biomass increases in the later growth stages (Coughtrey and Thorne, 1983). For spring wheat, Aarkrog (1969) and Eriksson et al. (1998) found similar results, ${ }^{134} \mathrm{Cs}$ accumulation in the seeds increases most in the later growth stages during foliar contamination of spring wheat by ${ }^{134} \mathrm{Cs}$ and ${ }^{85} \mathrm{Sr} .{ }^{85} \mathrm{Sr}$ concentrations in seeds were lower than those in straw, and in both cases, the highest concentration of ${ }^{85} \mathrm{Sr}$ was found when contamination occurred just before harvest. For spring oilseed rape, there is a lack of published data on the interception and transfer of radionuclides to seeds after deposition in growing crop.

All comparisons of radionuclide accumulation in seeds were significant except for spring wheat grain 2010 (Test 2 in Table $2,{ }^{85} \mathrm{Sr}$ activity concentration in seeds vs. ${ }^{134} \mathrm{Cs}$ activity concentration in seeds, by crop and by year, Supplementary data 4 for the plots). This indicates that the way the intercepted amount of radionuclide was transferred to the seeds was similar for both radionuclides. All comparisons between the two years were significant (test 3 in Table 2, 2010 seeds vs. 2011 seeds, by radionuclide and by crop, Supplementary data 4 for the plots), indicating the way the intercepted amount was transferred to the seeds did not differ between the two experimental years.

The lower transfer of ${ }^{134} \mathrm{Cs}$ and ${ }^{85} \mathrm{Sr}$ can be due to lower retention of radionuclides after fall-off in early growth stages (Colle et al., 2009), and in addition to dilution of the radionuclides due to rapid growth of the plant in early stages contributing to lower transfer factors (Colle et al., 2009; Eriksson et al., 1998). Several studies found that the highest transfer to cereal grains (barley, wheat, rice and rye), takes place after emergence of ears (Colle et al., 2009; Eriksson et al., 1998; Middleton, 1958, 1959; Vandecasteele et al., 2001; Voigt et al., 1991).

\subsection{Distribution of ${ }^{134} \mathrm{Cs}$ and ${ }^{85} \mathrm{Sr}$ between above ground plant parts}

The majority of the uptake of the radionuclides by the plants ended up in the straw, with a small amount being directed to the seeds (Supplementary data 2, for the distribution of plant material). In general, at harvest, the distribution of the radionuclides between the different plant parts of spring oilseed rape varied little between the different deposition occasions (Table 3 ); there was a tendency for ${ }^{134} \mathrm{Cs}$ to increase in siliques and the level-off or decrease in straw after deposition in late growth stages. In spring wheat, the largest amount of ${ }^{134} \mathrm{Cs}$ uptake was re-distributed to the straw, but a significant amount ended up in the grains in both years (Table 3). In 2011, more ${ }^{134} \mathrm{Cs}$ was redistributed to grain than to straw, and the ratio between the grain and straw biomass of the wheat plants was higher in 2010. In both years, the amount of ${ }^{134} \mathrm{Cs}$ tended to decrease in grain with respect to earlier growth stages at deposition; although in 2011, this trend was not observed for deposition at stage 89 . The redistribution of ${ }^{85} \mathrm{Sr}$ to grain was higher in 2011 than in 2010, but amounts in straw were still the highest. 
For ${ }^{85} \mathrm{Sr}$, no trend in changes of the distribution between plant parts as a function of deposition occasion was detected. These findings were in agreement with Bogdevitch et al. (2002), who studied root uptake of ${ }^{137} \mathrm{Cs}$ and ${ }^{90} \mathrm{Sr}$ in oilseed rape 12 years after the Chernobyl accident and found on average $65 \%$ of ${ }^{137} \mathrm{Cs}$ and $82 \%$ of ${ }^{90} \mathrm{Sr}$ went to the straw, with only $3 \%$ of ${ }^{137} \mathrm{Cs}$ and $6 \%$ of ${ }^{90} \mathrm{Sr}$ going to the seeds. Similarly, Putyatin et al. (2006) investigated root uptake and accumulation of ${ }^{137} \mathrm{Cs}$ and ${ }^{90} \mathrm{Sr}$ in different plant parts of spring wheat grown on a contaminated loamy san soil and found $85 \%$ of ${ }^{137} \mathrm{Cs}$ and $91 \%$ of ${ }^{90} \mathrm{Sr}$ in straw, and $18 \%$ of ${ }^{137} \mathrm{Cs}$ and $8 \%$ of ${ }^{90} \mathrm{Sr}$ in grain. The distribution pattern of radionuclides between the above ground plant parts after the radionuclides were applied to a growing crop was similar to other studies where uptake of radionuclides was entirely from the soil; this indicated the distribution of the radionuclides between above ground plant parts is independent of route of entrance (root or foliar uptake), but we do not know how much was taken up through the roots in any of the cases. There is a possibility that radionuclides fell directly onto the ground and were washed-off the plant surface, especially during deposition at early growth stages, which implies there might have been significant uptake from the soil after deposition. With this data alone, foliar and root uptake could not be distinguished, this required the data to be combined with a dynamical simulation model describing the dependency of foliar and root uptake on weather, growth stage, and radionuclide. This study focused on the distribution of the radionuclides among above ground plant parts. The proportion of radionuclides in the roots could be more dependent on the pathway. Moreover, it is not known how much is adsorbed on the surface or absorbed in the straw and siliques/husk. The uptake from soil in years following deposition is usually lower than in the year of deposition (Rosén, 1996).

\subsection{Transfer of ${ }^{134} \mathrm{Cs}$ and ${ }^{85} \mathrm{Sr}$ to seeds}

The TF values (Fig. 2) had the same trends as the harvested activity concentration of the radionuclides in the seeds (Table 1), as the amount of radioactivity per square meter was more or less the same applied in all treatments and on all occasions (i.e. the dominator in Equation (1) is constant). TLF (Fig. 3) were less correlated to the deposited activity concentration, as they were a function of the intercepted amount of activity (Equation (2)), which varied between deposition occasions. Despite the variation in magnitude of each transfer factor between different depositions occasions, they presented a similar pattern of the TF values: the 2010 interception data are presented in Bengtsson et al. (2012). For spring oilseed rape, interception was lowest on the first deposition occasion and remained constant for both radionuclides there after (Supplementary data 1, for values of interception). For spring wheat, interception was highest during deposition on the intermediate occasions. As the transfer factors tended to increase during the later deposition occasions (in 3 of 4 cases), interception alone did not explain the final activity concentration in the seeds. Other contributing factors may be the dilution of concentration due to growth of the biomass (Coughtrey and Thorne, 1983) and fall-off during the time from deposition to harvest (Colle et al., 2009; Eriksson et al., 1998). However, the TLF values should be more reliable than TF values, as they also consider the proportion of the deposited amount actually intercepted by the plant (Supplementary data 1 , for values of TF and TLF).

ANOVA was used to test whether the transfer was dependent on year, growth stage at deposition, type of crop, and type of radionuclide. In the ANOVA test, both the TF and TLF values for both radionuclides were dependent on the growth stage of the crop ( $p<$ $0.0001)$, the type of crop $(p<0.0001)$, and the year $(p$ $<0.0001)$, but not the type of radionuclide $(p>0.005)$. When the two crops were compared (Figs. 2 and 3), both TF and TLF values had similar orders of magnitude in 2010, but in 2011, the transfer tended to be higher for spring wheat grain than for seed of spring oilseed rape. However, the transfer in 2011 was higher for spring oilseed rape than for spring wheat, for the depositions occurring in the end of the growing season close to harvest. The transfer was higher in 2011 than in 2010 .

The range in $\mathrm{TF}$ values for spring wheat was $<0.000-0.060$ for ${ }^{134} \mathrm{Cs}$ and $<0.000-0.065$ for ${ }^{85} \mathrm{Sr}$ : Eriksson et al. (1998) found a similar range in $\mathrm{TF}$ values for spring wheat $\left({ }^{134} \mathrm{Cs}: 0.001-0.112 ;{ }^{85} \mathrm{Sr}\right.$ : 0.000-0.032). In a similar experiment, Vandecasteele et al. (2001) used ${ }^{137} \mathrm{Cs}$ and ${ }^{90} \mathrm{Sr}$, and found TLF values for spring wheat to be much lower $\left({ }^{137} \mathrm{Cs}\right.$ : $\left.0.003-0.031 ;{ }^{90} \mathrm{Sr}:<0.000-0.003\right)$ as reported in the present study $\left({ }^{134} \mathrm{Cs}: 0.027-0.59 ;{ }^{85} \mathrm{Sr}: 0.005-0.45\right)$. However, even if the transfer factors for spring wheat were in accordance with other studies, the variation in the TF and TLF values was corroborated by the different results for the two experimental years. This rendered the use of these values for predicting possible contamination of food items in a real situation as uncertain. Thus, preliminary assessments of activity concentrations in crops need to be continuously sampled and monitored.

\section{Conclusions}

The highest transfer of radionuclides to seeds was when deposition was during at the growth stages closest to harvest. Spring oilseed rape seed preferred 
${ }^{134} \mathrm{Cs}$, whereas, spring wheat grains preferred ${ }^{85} \mathrm{Sr}$. The activity concentration of both radionuclides generally increased in order: grain < straw < husks for spring wheat. Therefore, it was conclude the highest risk for transfer of radionuclides to humans via the food chain was when the deposition occurred towards the end of the growing season.

The majority of radionuclide uptake by plant was distributed to the straw, whereas, a small amount was directed to the seeds in spring oilseed rape. In spring wheat a small part was directed to the husk, and the amount of ${ }^{134} \mathrm{Cs}$ varied between the experimental years. The proportion of radionuclides in plant parts at harvest and showed to be independent of the deposition occasion, even though it could be assumed deposition at early growth stages meant significant root uptake, whereas, at later stages, a majority of deposition was intercepted and directly taken up by the plants through the leaves.

At later growth stages, majority of the deposited amount can be prevented from reaching the soil if both straw and seeds of a strongly polluted crop are harvested and removed from the field. This would presumably reduce root uptake of the radionuclides by crops in subsequent years.

The relative variation in magnitude of each transfer factor (TF and TLF) among different deposition occasions followed a similar pattern. Transfer factors relating activity concentrations in seed at harvest to deposition of radionuclides in growing oilseed crops are to date unpolished, although a number of transfer factors for spring wheat are already available. The variation between years in this investigation and among earlier published transfer factors stresses the need for further field and modeling experiments, on both spring oilseed rape and spring heat, to improve understanding of the mechanisms causing the variation, which can be used for reliable predicting radionuclides in seeds after possible future radioactive fallout due to a nuclear accident and testing of nuclear weapons.

\section{Acknowledgements}

This project was financed by the Swedish Radiation Safety Authority and by the Swedish Board of Agriculture. We thank the staff of the Radioecology section, especially MSc Yosief Tesfatsion and MSc Anna-Lisa Mårtensson, at the Department of Soil and Environment, Swedish University of Agricultural Sciences, and Mr Giovanni Nigrinis for illustrating the growth stages of spring oilseed rape and for help with fieldwork. We thank our colleagues in the Biogeochemistry and Environmental Assessment research group, especially MSc Martin Rappe George, for essential and supportive discussions about the results in this paper. We finally thank PhD Mikael Andersson Franko at the Department of Economics, Swedish University of Agricultural Sciences for statistical advice and MSc Sue Pajuluoma for proofreading the language.

\section{Appendix A. Supplementary data}

Supplementary data related to this article can be found at http://dx.doi.org/10.1016/j.envpol.2013.07.035

\section{References}

Aarkrog, A., 1969. On direct contamination of rye, barley, wheat and oats with ${ }^{85} \mathrm{Sr},{ }^{134} \mathrm{Cs},{ }^{54} \mathrm{Mn}$ and ${ }^{141} \mathrm{Ce}$. Radiation Botany 9, 357-366.

Aarkrog, A., 1975. Radionuclide levels in mature grain related to radiostrontium content and time of direct contamination. Health Physics 28, 557-562.

Aarkrog, A., 1983. Translocation of radionuclides in cereal crops. In: Coughtrey, P.J. (Ed.), Ecological Aspects of Radionuclide Release. Blackwell Scientific Publications, Oxford, pp. 81-90.

Bayer Crop Science, 2011. Utvecklingsstadier vete och potatis.

Bengtsson, S.B., Eriksson, J., Gärdenäs, A.I., Rosén, K., 2012. Influence of development stage of spring oilseed rape and spring wheat on interception of wet-deposited radiocaesium and radiostrontium. Atmospheric Environment 60, 227-233.

Bogdevitch, I., Putyatin, Y., Rigney, C., Chupov, A., 2002. Edible Oil Production from Rapeseed Grown on Contaminated Lands. In: Innovationsforum westschopfugsketten in der naturstoffverarbeitung, pp. 148156.

Bréchignac, F., Vallejo, R., Vandecasteele, C., Shaw, G., Forsberg, S., Madoz-Escande, C., 2000. Improving the Short and Long Term Prediction Ability of Radiocontaminant Behavior in Agro-Ecosystems. Rapport Scientifique et Technigue IPSN - RST 2000.

Bronson, F., Atrashkevich, V., Geurkov, G., Young, B., 2008. Probabilistic uncertainty estimator for gammaspectroscopy measurements. Journal of Radioanalytical and Nuclear Chemistry 276, 589-594.

Canberra, I., 2009. Genie ${ }^{\mathrm{TM}}$ 2000, 3.2.1 ed. Meriden.

Colle, C., Madoz-Escande, C., Leclerc, E., 2009. Foliar transfer into the biosphere: review of translocation factors to cereal grains. Journal of Environmental Radioactivity 100, 683-689.

Coughtrey, P.J., Thorne, M.C., 1983. Radionuclide Distribution and Transport in Terrestrial and Aquatic Ecosystems a Critical Review of Data. A.A.Balkema, Rotterdam.

Department of Crop Production Ecology, 2013. SLU Ultuna Climate. Swedish University of Agricultural Sciences, Uppsala, Sweden.

Ehlken, S., Kirchner, G., 2002. Environmental processes affecting plant root uptake of radioactive trace elements and variability of transfer factor data: a review. Journal of Environmental Radioactivity 58, 97-112. 
Eichert, T., Burkhardt, J., 2001. Quantification of stomatal uptake of ionoc solutes using a new model system. Journal of Experimental Botany 52, 771-781.

Eichert, T., Burkhardt, J., Goldbach, H.E., 2002. Some factors controlling stomatal uptake. In: Tagliavini, M., Toselli, M., Bertschinger, L., Neilsen, D., Thalheimer, M. (Eds.), Proceedings of the International Symposium on Foliar Nutrition of Perennial Fruit Plants, pp. 85-90.

Ellison, S.L.R., Rosslein, M., Williams, A., 2000. Quantifying Uncertainty in Analytical Measurement. EURACHEM/CITAC, p. 120

Eriksson, A., Rosén, K., Haak, E., 1998. Retention of Simulated Fallout Nuclides in Agricultural Crops, II. Deposition of Cs abd Sr on Graon Crops, SLU-REK-81. Institutionen for radioekologi, SLU, p. 36.

Hack, H., Bleiholder, H., Buhr, L., Meier, U., SchnockFricke, U., Weber, E., Witzenberger, A., 1992. Einheitliche Codierung der phänologischen Entwicklungsstadien mono- und dikotyler Pflanzen. Erweiterte BBCH-Skala, Allgemein-. Nachrichtenblatt des Deutschen Pflanzenschutzdienstes 44, 265-270.

Handley, R., Babcock, K.I., 1972. Translocation of ${ }^{85} \mathrm{Sr}$, ${ }^{137} \mathrm{Cs}$, and ${ }^{106} \mathrm{Ru}$ in crop plants. Radiation Botany 12,113 119.

Hossain, M.B., Ryu, K.S., 2009. Effects of foliar applied phospatic fertilization on absorption pathways, yield and quality of sweet persimmon. Scientia Horticulturae 122, 626-632.

Howard, B.J., Johansson, K., Linsley, G.S, Hove, K., Pröhl, G., Horyna, J., 1996. Transfer of Radionuclides by Terrestrial Food Products from Semi-natural Ecosystems to Humans, Modelling of Radionuclide Interception and Loss Processes in Vegetation and of Transfer in Seminatural Ecosystems. IAEA-TECDOC-857. International Atomic Energy Agency, Vienna, p. 84.

IAEA, 2010. Handbook of Parameter Values for the Prediction of Radionuclide Transfer in Terrestrial and Freshwater Environments, p. 208. Technical Reports Series No. 472, Vienna.

ISO, 1993. Guide to the Expression of Uncertainty in Measurement, Geneva, p. 101.

Joel, A., Messing, I., 2001. Infiltration rate and hydraulic conductivity measured with rain simulator and disc permeameter on sloping arid land. Arid Land Research and Management 15, 371-384.

Karlsson, S., Fagerberg, B., 1995. Klimat- och Bioklimatstationen vid Ultuna, Historik och Framtid (The climate and bioclimate station at Ultuna, Swedish University of Agricultural Sciences). Department of Crop Production Ecology, Swedish University of Agricultural Sciences, Uppsala, p. 25.

Kinnersley, R.P., Goddard, A.J.H., Minski, M.J., Shaw, G., 1997. Interception of caesium-contaminated rain by vegetation. Atmospheric Environment 31, 1137-1145.

Kirchmann, H., Fagniart, E., van Puymbroeck, S., 1967. Studies on foliar contamination by radiocaesium and radiostrontium. In: Åberg, B., Hungate, F.P. (Eds.), Radioecology Concentration Processes, Stockholm, pp. 475-483.

Kostiainen, E., Hänninen, R., Rosén, K., Haak, E., Eriksson, A., Nielsen, S., Keith-Roach, M., Salbu, B., 2002. Transfer Factors for Nuclear Emergency Preparedness.
Report from the NKS/BOK-1.4. Project Group Countermeasures in Agriculture and Forestry, Roskilde, p. 76.

Middleton, L.J., 1958. Absorption and translocation of strontium and caesium by plants from foliar sprays. Nature 181, 1300-1303.

Middleton, L.J., 1959. Radioactive strontium and caesium in the edible parts of crop plants after foliar contamination. International Journal of Radiation Biology and Related Studies in Physics Chemistry and Medicine 1, 387-402.

Müller, H., Pröhl, G., 1993. ECOSYS-87: a dynamical model for assessing radiological consequences of nuclear accidents. Health Physics 64, 232-252.

Pröhl, G., 2009. Interception of dry and wet deposited radionuclides by vegetation. Journal of Environmental Radioactivity 100, 675-682.

Putyatin, Y.V., Seraya, T.M., Petrykevich, O.M., Howard, B.J., 2006. Comparison of the accumulation of Cs-137 and $\mathrm{Sr}-90$ by six spring wheat varieties. Radiation and Environmental Biophysics 44, 289-298.

Rosén, K., 1996. Transfer of radiocaesium in sensitive agricultural environments after the Chernobyl fallout in Sweden. II. Marginal and semi-natural areas in the county of Jämtland. Science of the Total Environment 182, 135 145.

Rosén, K., Eriksson, A, Haak, E., 1996. Transfer of radiocaesium in sensitive agricultural environments after the Chernobyl fallout in Sweden. I. County of Gävleborg. Science of the Total Environment 182, 117-133.

Rosén, K., von Fircks, Y., Vinichuk, M., Sennerby-Forsse, L., 2011. Accumulation of (137)Cs after potassium fertilization in plant organs of Salix viminalis $\mathrm{L}$. and in combusted ash. Biomass \& Bioenergy 35, 2765-2772.

Salbu, B., 2000. Speciation of radionuclides in the environment. In: Meyers, R.A. (Ed.), Encyclopedia of Analytical Chemistry: Applications, Theory and Instrumentations, Nuclear Magnetic Resonance and Electron Spin Resonance, vol. 14. John Wiley \& Sons Ltd, Chichester, pp. 12993-13016.

SMHI, 2012. Klimatdata för miljöövervakning. Swedish Meteorological and Hydrological Institute, Norrköping.

The R Foundation for Statistical Computing, 2012. R, 2.15.2 Eed, Vienna.

Thiessen, K.M., Thorne, M.C., Maul, P.R., Pröhl, G., Wheater, H.S., 1999. Modelling radionuclide distribution and transport in the environment. Environmental Pollution 100, 151-177.

Tukey, H.B., Bukovac, M.J., Wittwer, S.H., 1961. Absorption of radionuclides by aboveground plant parts and movement within plant. Journal of Agricultural and Food Chemistry 9, 106-113.

Vandecasteele, C.M., Baker, S., Forstel, H., Muzinsky, M., Millan, R., Madoz-Escande, C., Tornos, J., Sauras, T., Schulte, E., Colle, C., 2001. Interception, retention and translocation under greenhouse conditions of radiocaesium and radiostrontium from a simulated accidental source. Science of the Total Environment 278, 199-214.

Voigt, G., Pröhl, G., Müller, H., 1991. Experiments on the seasonality of the cesium translocation in cereals, potatoes and vegetables. Radiation and Environmental Biophysics 30, 295-303. 
Weber, E., Bleiholder, H., 1990. Explanations of the BBCH decimal codes for the growth stages of maize, rape, faba beans, sunflowers and peas - with illustrations. Gesunde Pflanzen 42, 308-321.
Zadoks, J.C., Chang, T.T., Konzak, C.F., 1974. A decimal code for the growth stages of cereals. Weed Research 14, 415-421.
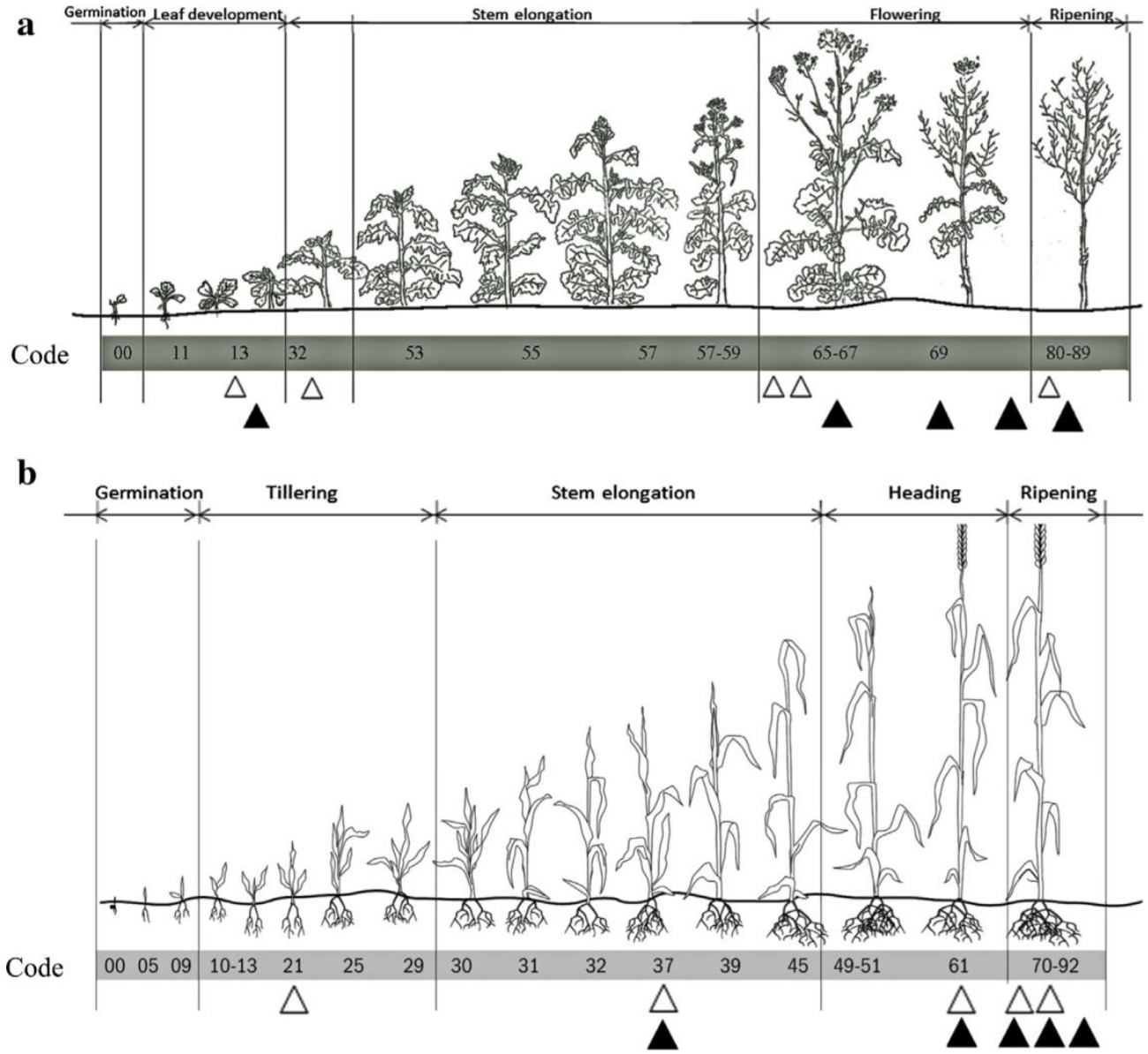

Fig. 1. a Growth stages in spring oilseed rape. Triangles indicate the stages of deposition in $2010(\Delta)$ and in 2011 ( $\mathbf{\Delta}$ ). Illustration of the BBCH-scale by Giovanni Nigrinis (after Weber and Bleiholder, 1990). b. Growth stages in spring wheat. Triangles indicate the stages of deposition in $2010(\Delta)$ and in $2011(\Delta)$. Illustration with permission from Bayer Crop Science (2011), based on Zadoks et al. (1974). 

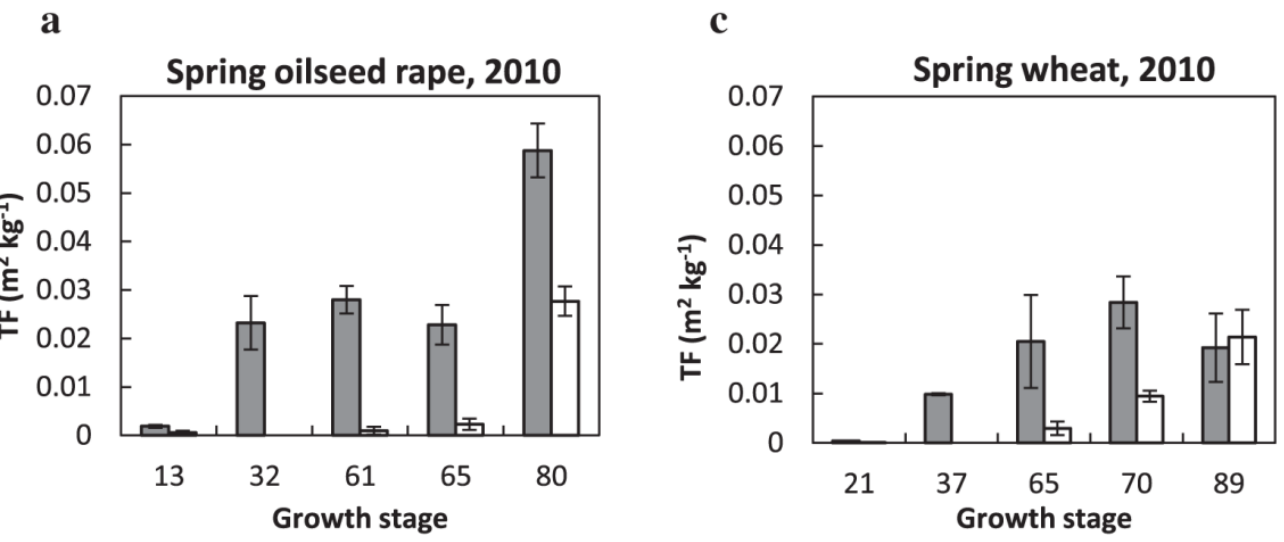

b
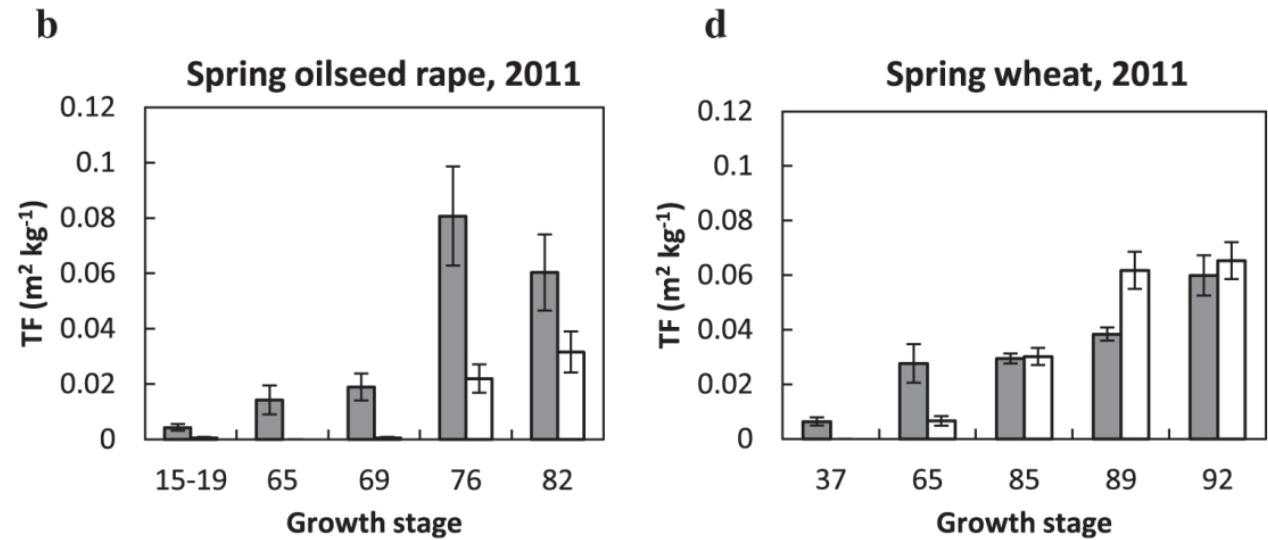

Fig. 2. a-d. Mean transfer factors (TF) $\left(\mathrm{m}^{2} \mathrm{~kg}^{-1}\right)$ of ${ }^{134} \mathrm{Cs}(\mathbf{m})$ and ${ }^{85} \mathrm{Sr}(\square)$ for seeds after wet-deposition at five different growth stages in spring oilseed rape and spring wheat. The number of observations is on average $n=3$ for all growing stages; except spring oilseed rape (2011, 2b), $n=2$ at growing stages 65 for ${ }^{134} \mathrm{Cs}$. Error bars indicate standard error of the mean (SEM). 
$\mathbf{a}$

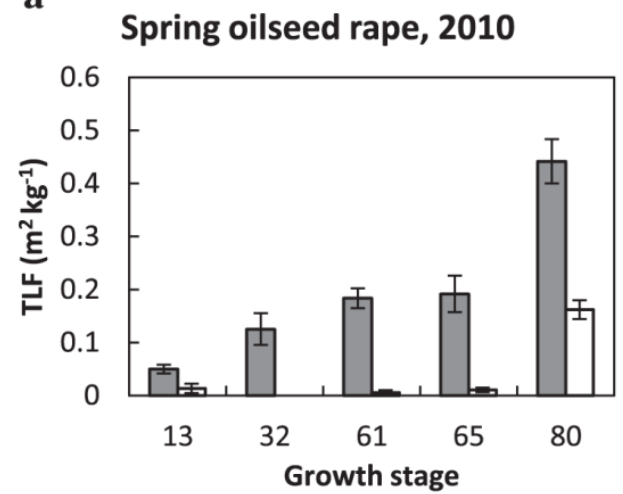

b

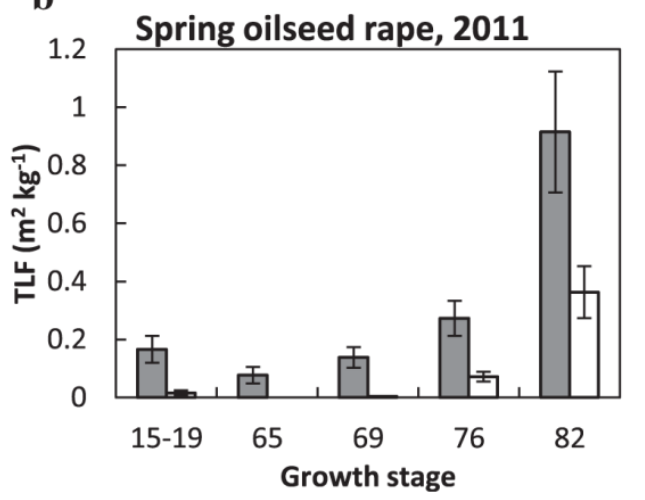

c

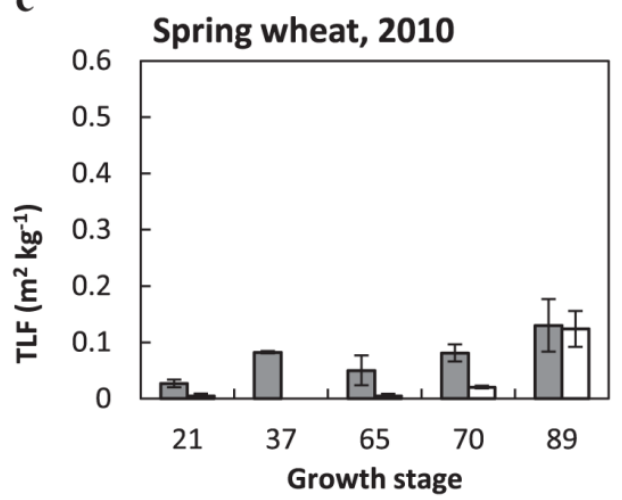

d

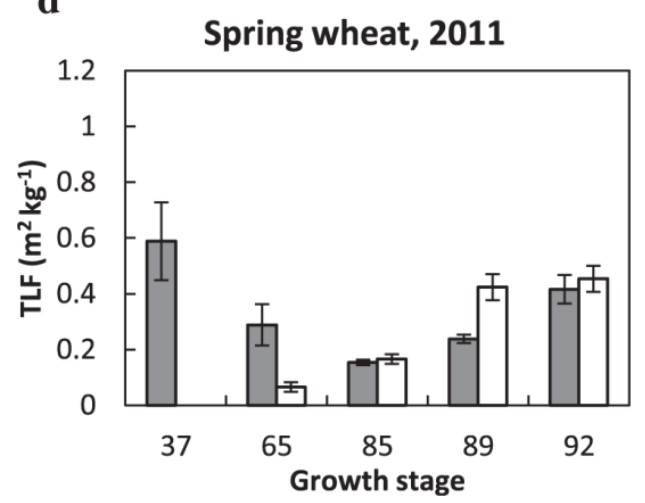

Fig. 3. a-d. Mean translocation factors (TLF) $\left(\mathrm{m}^{2} \mathrm{~kg}^{-1}\right)$ of ${ }^{134} \mathrm{Cs}(\mathbf{\square})$ and ${ }^{85} \mathrm{Sr}(\square)$ for seeds after wet-deposition at five different growth stages in spring oilseed rape and spring wheat. The number of observations is on average $n=3$ for all growing stages, except spring oilseed rape (2011, 3b), $n=2$ at growing stage 65 for ${ }^{134} \mathrm{Cs}$. Error bars indicates standard error of the mean $(S E M)$. 
Table 1. Activity concentrations of ${ }^{134} \mathrm{Cs}$ and ${ }^{85} \mathrm{Sr}\left(\mathrm{Bq} \mathrm{kg}^{-1}\right)$ in different plant parts at harvest (September) after wet-deposition at different growth stages in spring oilseed rape and spring wheat. The means and ranges are of three replicates $(n=3)$, except where $t n=2$. Values with $(*)$ are below minimum detectable activity.

\begin{tabular}{|c|c|c|c|c|c|c|c|c|c|}
\hline \multirow{2}{*}{$\begin{array}{l}\text { Year / } \\
\text { Crop }\end{array}$} & \multirow{2}{*}{$\begin{array}{l}\text { Growth } \\
\text { stage at } \\
\text { deposition }\end{array}$} & \multicolumn{4}{|l|}{${ }^{134} \mathrm{Cs}$} & \multicolumn{4}{|l|}{${ }^{85} \mathrm{Sr}$} \\
\hline & & Seeds & Siliques (except seeds) & Straw & Whole plant & Seeds & Siliques (except seeds) & Straw & Whole plant \\
\hline $2010 /$ & 13 & $46(34-64)$ & $16(0-48)$ & $39(31-47)$ & $36(29-42)$ & $25(0-65)$ & $23(0-70)$ & $65(23-141)$ & $49(5-128)$ \\
\hline \multirow[t]{4}{*}{ Oilseed } & 32 & $622(415-983)$ & $1217(966-1530)$ & $917(655-1230)$ & $918(692-1225)$ & $<65^{*}$ & $57(20-100)$ & $67(0-201)$ & - \\
\hline & 61 & $725(598-900)$ & $1423(1350-1510)$ & $600(570-644)$ & $771(716-846)$ & $40(0-120)$ & $303(160-530)$ & $111(0-224)$ & $135(34-209)$ \\
\hline & 65 & $612(354-805)$ & $1227(1010-1360)$ & $482(341-565)$ & $639(486-725)$ & $87(0-137)$ & $800(550-1140)$ & $219(70-305)$ & $313(184-425)$ \\
\hline & 80 & $1816(1416-2126)$ & $2590(1900-3410)$ & 11183 (8376-14986) & $3284(2398-4436)$ & $1379(1111-1733)$ & 14767 (11400-19800) & $3757(3060-4970)$ & $5534(4417-7477)$ \\
\hline $2011 /$ & $15-19$ & $174(85-287)$ & $127(60-220)$ & $223(149-312)$ & $189(106-286)$ & $20(0-46)$ & $33(0-60)$ & $24(0-73)$ & $24(0-59)$ \\
\hline \multirow[t]{5}{*}{ Oilseed } & 65 & $583(279-888)^{\ddagger}$ & $370(320-420)^{*}$ & $573(358-787)^{\ddagger}$ & $519(357-681)^{\ddagger}$ & $<24 *$ & $25(0-50)^{\ddagger}$ & $<35^{*}$ & - \\
\hline & 69 & $769(520-1256)$ & $973(700-1250)$ & $860(360-1210)$ & $851(489-1123)$ & $30(15-45)$ & $117(90-170)$ & $15(0-45)$ & $42(22-52)$ \\
\hline & 76 & $3308(2342-5101)$ & $3000(2070-4500)$ & $2280(1910-2480)$ & $2656(2100-2978)$ & $902(625-1416)$ & $2017(1300-3030)$ & 344 (139-687) & $812(487-1417)$ \\
\hline & 82 & $2448(1123-3401)$ & 7477 (1970-10800) & $3940(2550-5900)$ & $4545(2005-6421)$ & $1281(579-1824)$ & $5160(1060-9730)$ & $1663(1550-1730)$ & $2477(1409-3852)$ \\
\hline & & Grain & Husk & Straw & Whole plant & Grain & Husk & Straw & Whole plant \\
\hline $2010 /$ & 21 & $6(0-11)$ & $60(0-180)$ & $8(0-24)$ & $9(3-11)$ & $3(0-9)$ & $7(0-20)$ & $<46^{*}$ & - \\
\hline \multirow[t]{4}{*}{ Wheat } & 37 & $263(255-275)$ & $470(380-520)$ & $447(360-530)$ & $399(317-475)$ & $<6^{*}$ & $<164^{*}$ & $374(227-526)$ & - \\
\hline & 65 & $677(466-981)$ & $1503(930-2500)$ & $1343(1030-1910)$ & $1091(853-1528)$ & $121(0-241)$ & $1293(550-2160)$ & $912(606-1280)$ & $618(416-858)$ \\
\hline & 70 & $761(500-982)$ & $2347(2070-2700)$ & $1877(1340-2440)$ & $1385(1015-1806)$ & $362(281-461)$ & $2130(2030-2240)$ & $2293(1750-2730)$ & $1396(1153-1522)$ \\
\hline & 89 & $594(357-1020)$ & 7937 (5300-12200) & $4073(3270-4880)$ & $2558(1868-2936)$ & $1065(613-1720)$ & $15167(10700-22500)$ & $7223(7780-10500)$ & $5672(4170-7197)$ \\
\hline $2011 /$ & 37 & $257(109-348)$ & $413(400-426)^{\ddagger}$ & $298(113-491)$ & $359(336-381)^{\ddagger}$ & $<7^{*}$ & $104(70-138)^{\ddagger}$ & $244(54-488)$ & - \\
\hline \multirow[t]{4}{*}{ Wheat } & 65 & $1133(605-1810)$ & $1209(757-1880)$ & $728(0-1480)$ & $1053(544-1703)$ & $2403(1341-4290)$ & $1135(425-1090)$ & $921(0-1900)$ & $593(159-1116)$ \\
\hline & 85 & $1207(1050-1370)$ & $3927(2270-5150)$ & $1530(1370-1710)$ & 1635 (911-1717) & $1237(922-1420)$ & $6087(3520-7900)$ & $2837(2440-3060)$ & $2295(1683-2608)$ \\
\hline & 89 & $1567(1400-1800)$ & $8485(5680-11290)^{\ddagger}$ & $3095(2110-4025)$ & $2001(2215-3788)^{\ddagger}$ & $2494(1880-3037)$ & $12325(9250-15400)^{\ddagger}$ & $6312(3090-10436)$ & $4829(3183-6475)^{\ddagger}$ \\
\hline & 92 & $2430(1890-3130)$ & $27273(25300-30520)$ & $11300(10400-13000)$ & $8156(7335-8929)$ & $2650(2030-3180)$ & $25543(23100-28730)$ & $11900(10700-13400)$ & $8262(7540-8771)$ \\
\hline
\end{tabular}


Table 2. Selected linear regression models for estimating activity concentration in the two crops.

\begin{tabular}{lllll}
\hline & $\operatorname{Adj}^{2}$ & $P$ & $d y / d x$ & Intercept \\
\hline Test 1 & & & & \\
${ }^{134} \mathrm{Cs} 2010$ both crops & 0.74 & $<0.001$ & 0.92 & 0.00 \\
${ }^{134} \mathrm{Cs} 2011$ both crops & 0.83 & $<0.001$ & 1.43 & 0.00 \\
${ }^{85} \mathrm{Sr} 2010$ both crops & 0.81 & $<0.001$ & 1.35 & 0.00 \\
${ }^{85} \mathrm{Sr} 2011$ both crops & 0.75 & $<0.001$ & 3.02 & 0.00 \\
${ }_{\text {Test 2 }}$ & & & & \\
Oilseed rape seed 2010 & 0.73 & $<0.001$ & 0.56 & 0.00 \\
Oilseed rape seed 2011 & 0.84 & $<0.001$ & 0.35 & 0.00 \\
Spring wheat grain 2010 & 0.51 & $<0.05$ & 0.77 & 0.00 \\
${ }^{\text {Spring wheat grain 2011 }}$ & 0.86 & $<0.001$ & 0.81 & 0.00 \\
${ }_{\text {Test 3 }}$ & & & & \\
${ }^{134} \mathrm{Cs}$ oilseed rape seed & 0.54 & $<0.05$ & 1.57 & 0.00 \\
${ }^{134} \mathrm{Cs}$ spring wheat grain & 0.71 & $<0.001$ & 2.29 & 0.00 \\
${ }^{85} \mathrm{Sr}$ oilseed rape seed & 0.56 & $<0.001$ & 0.94 & 0.00 \\
${ }^{85} \mathrm{Sr}$ spring wheat grain & 0.65 & $<0.001$ & 2.60 & 0.00 \\
\hline
\end{tabular}

Table 3. Percentages of ${ }^{134} \mathrm{Cs}$ and ${ }^{85} \mathrm{Sr}$ in different plant parts of stages in spring oilseed rape and spring wheat at harvest (September) after wet-deposition at different growth stages. Means are from three replicates $(n=3)$, except where $\not n=2$. The percentage not estimated due to activity below minimum detectable limit is denoted by*.

\begin{tabular}{|c|c|c|c|c|c|c|c|}
\hline \multirow{2}{*}{$\begin{array}{l}\text { Year / } \\
\text { Crop }\end{array}$} & \multirow{2}{*}{$\begin{array}{l}\text { Growth } \\
\text { stage at } \\
\text { deposition }\end{array}$} & \multicolumn{3}{|l|}{${ }^{134} \mathrm{Cs}$} & \multicolumn{3}{|l|}{${ }^{85} \mathrm{Sr}$} \\
\hline & & Seeds & $\begin{array}{l}\text { Siliques (except } \\
\text { seeds) }\end{array}$ & Straw & Seeds & $\begin{array}{l}\text { Siliques (except } \\
\text { seeds) }\end{array}$ & Straw \\
\hline $2010 /$ & 13 & 20 & 8 & 72 & 14 & 14 & 72 \\
\hline \multirow{4}{*}{ Oilseed } & 32 & 11 & 25 & 64 & $*$ & $*$ & $*$ \\
\hline & 61 & 14 & 34 & 52 & 3 & 57 & 40 \\
\hline & 65 & 13 & 37 & 50 & 6 & 50 & 44 \\
\hline & 80 & 8 & 39 & 53 & 4 & 51 & 45 \\
\hline $2011 /$ & $15-19$ & 21 & 15 & 64 & 13 & 31 & 56 \\
\hline \multirow[t]{5}{*}{ Oilseed } & 65 & $16^{\ddagger}$ & $18^{\ddagger}$ & $66^{\ddagger}$ & $*$ & $*$ & $*$ \\
\hline & 69 & 23 & 32 & 45 & 9 & 79 & 12 \\
\hline & 76 & 21 & 25 & 54 & 18 & 37 & 45 \\
\hline & 82 & 17 & 44 & 39 & 19 & 49 & 32 \\
\hline & & Grain & Husk & Straw & Grain & Husk & Straw \\
\hline $2010 /$ & 21 & 49 & 18 & 33 & $*$ & $*$ & $*$ \\
\hline \multirow[t]{4}{*}{ Wheat } & 37 & 34 & 6 & 60 & $*$ & $*$ & $*$ \\
\hline & 65 & 34 & 4 & 62 & 7 & 6 & 87 \\
\hline & 70 & 24 & 7 & 69 & 11 & 7 & 82 \\
\hline & 89 & 11 & 16 & 73 & 10 & 15 & 75 \\
\hline $2011 /$ & 37 & 35 & $9^{\ddagger}$ & $56^{\ddagger}$ & $*$ & $*$ & $*$ \\
\hline \multirow[t]{4}{*}{ Wheat } & 65 & 68 & 16 & 16 & 36 & 28 & 36 \\
\hline & 85 & 44 & 28 & 28 & 32 & 31 & 37 \\
\hline & 89 & $35^{\ddagger}$ & $35^{\ddagger}$ & $30^{\ddagger}$ & $31^{\ddagger}$ & $33^{\ddagger}$ & $36^{\ddagger}$ \\
\hline & 92 & 17 & 40 & 43 & 18 & 37 & 45 \\
\hline
\end{tabular}

